\title{
The Spiritual And Religious Practice Of "Jeedo"Among Elderly Women In Bauchi Emirate Of North Eastern Nigeria
}

\author{
Abubakar Yakubu ${ }^{*}$, Mohammed Mustapha Namadi ${ }^{2}$ \\ ${ }^{1}$ Department of Sociology \\ Federal University Kashere, Gombe State - Nigeria, NIGERIA \\ ${ }^{2}$ Department of Sociology \\ Federal University Kashere, Gombe State - Nigeria, NIGERIA \\ *Corresponding Author : yakubua7@gmail.com
}

DOI: https://doi.org/10.30880/jts.2018.10.01.001

\begin{abstract}
Population ageing has been identified as one of the most potential crises across the globe that requires urgent attention. One of the most crucial issues related to this development is the issue of the quality life of older adults. The study describes a spiritual practice among elderly women that has stood the test of time, referred to as Jeedo. The study uses participatory research methods and data was analyzed using thematic analysis. Findings revealed that, the Jeedo has been practiced for over two hundred as system of spiritual devotion and getting closer to Allah (SWT) in preparation for death. The practice has eventually expanded into a formidable network of elderly women who are devoted to the service of the society and mutual help within them. It is recommended that, with empowerment sensitization and change of attitude the Jeedo can be modelled across the eastern Nigeria and beyond.
\end{abstract}

Keywords: Religious practice, jeedo, elderly woman

\section{Introduction}

There growing concerns regarding older adults' quality of life follows the continued increase in size of older adult's population (Huang, 2003; Peterson, 2001). The increase has been noted to include older adult's experience of a number of vulnerabilities such as an increase in physical, mental, and emotional health issues, in addition to significant variations in social and economic existence (Lubben, Gironda, Berkman, \& Harootyan, 2003). In the face of these inevitable late life challenges, spirituality is often identified as a significant source of strength and resiliency in the lives of older adults age 65 and over(Collins, Furman, Hackman, Bender, \& Bruce, 2007; Lewis-Williams, D. J., \& Pearce, 2004).

The challenges of later life imply the need to re-define the meaning of life, in ways capable of strengthening the capacity to cope. In this regard, a consensus exists within a considerable number of studies that, religiosity and spirituality are important aspects of coping with the inevitable despair, that accompanies this stage of the life circle. Practices in spirituality and religion have been supported by an overwhelming evidence, for positive outcomes, among older adults(Atchley, R. C., \& Barusch, 2000; Zimmer et al., 2016).

The Jeedo is a spiritual and religious practice that has been practice for centuries, among elderly women in Bauchi emirate north eastern Nigeria. The word Jeedo from its Hausa meaning refers to the spirit of labor and diligence, literally reflecting the spirit with which the Jeedo is practiced. Through such a spirit, different religious tasks are performed by the Jeedo members under the instruction of their leader known as "Jeedo". The aim remains spirituality and religious duty. The relevance of the Jeedo practices to the elderly women differs from other religious and spiritual 
practices of devotion. Unlike the suluk and Pondok systems in the Malay world, the Jeedo is a preparation for passing in grace towards death. (Omar, 1999).

The Jeedo practice is a source of both spiritual and religious coping among its adherents. The objectives of the study are to describe the practice of Jeedo among the elderly women practicing it, and the role played by rituals of the Jeedo in preparation for death among the elderly women in Bauchi Emirate in North-eastern Nigeria.

\subsection{Conceptual Clarifications}

\section{Spirituality}

The point of view for many Gerontologists about spirituality, is that of a basic value, through which a focus is maintained in realizing or pursuing all other values. This makes spirituality to be considered as the central philosophy of life. The Values pursued through spirituality as a philosophy of life, include both the religious, antireligious, and nonreligious search for meaning to life. Spirituality is the source of guide and inspiration for conduct with the supernatural and nonmaterial dimensions of existence (Moberg, 2005).

Zinnbauer \& Pargament, (2005) explained that, spirituality is a search for the sacred. It is a search for that aspect of human nature, which is special, and set apart from the commonplace, and deserve to be worshiped. Spirituality in one's life and may include a belief in God. In practice, spirituality is regarded as higher state of fluidity, than religion. The reason being that religion is "an institutional pattern of beliefs, behaviors, and experiences, orientated toward spiritual concerns, shared by a community and transmitted over time in traditions" (Furman, Benson, Canda, \& Grimwood, 2005). Therefore religion leads to spirituality.

\section{Religion}

The concept of religion encompasses an orderly body of beliefs and organized practices. Within a community, religion exist as a formal activity engaged by members in their search for spirituality (Cornett, 1992; Nelson Becker, et al., 2007; Sermabeikian, 1994). For many, religion is a route to spirituality. Both religion and spirituality can bring meaning to life.

\section{Religiosity}

Religiosity refers to excessive devoutness or devotion to a religious, religiosity is synonymous with such terms like religiousness, faith, belief, piety, orthodoxy, devotion, and holiness (Beckford \& Demerath, 2007; Lewis \& Tollefsen, 2016). Religiosity can be defined as the degree to which individual endorses a relationship with God or a transcendent force. As a consequence, such degree of endorsement an individual discovers meaning and purpose to the existence in this world. Religiosity essentially exerts significant influence on how a religious person operates in the world (Armstrong, Development, \& 2002.; Berkel, Armstrong, \& Cokley, 2004). Examples from sociological analysis includes; church membership, church attendance, belief acceptance, doctrinal knowledge, and living the faith.

The terms religiousness/religiosity are often used interchangeably. However, both aimed at explaining the extent of an individual's conviction, piety, and worship towards a holy entity. The concept can also have narrowed down to mean an extreme view or excessive dedication to religious rituals and traditions. When religiosity becomes rigid it is often viewed as a negative experience beyond the social norm of faith. Several types of religiousness include; religious affiliation, attending religious services, and motivation towards religious participation. Religious motivation can be intrinsic and extrinsic where as individuals with an intrinsic orientation are guided daily in their activities and by their religious beliefs, extrinsically motivated individuals use religion for private or social rewards. These include life comfort or fellowship (Allport, psychology, \& 1967).

\section{Spirituality and Religiosity}

There exists a consensus among considerable number of scholars that, spirituality and religion are related constructs (Zimmer et al., 2016). Although Spirituality and religion are separate variables for analysis, in practice they are tightly related concepts. The main reason being that, the concept of spirituality is wider and usually attained through a religious practice(Zinnbauer \& Pargament, 2005). Furthermore, religion refers to the search for meaning through the ways believed by adherents to relate with the sacred. Therefore, Spirituality is as a pursuit for meaning to the vagaries of life, Spiritually can also be attained through a relationship with God, transcendent and others (Babatunji et al., 2015; MacKinlay \& Burns, 2017)( MacKinlay \& Trevitt, 2010; Nelson-Becker et al., 2007; Schlehofer, Omoto \& Adelman, 2008; Snodgrass \& Sorajjakool, 2011; Yoon \& Lee, 2007).

\section{Old age}

Old age or senescence stage, refers to final stage in an organism's normal life span. However, in humans, there exist no single position on the age at which a person becomes old. (Little 2013). As such the "elderly" are regarded as those 60 years and over. Within this categories, further classifications are; the young old from the age of 60 to 74, the aged, from the age of 75 and above, the oldest old, from the age of 80 , and the oldest old, from the age of 85 and over (National Population Commission (NPC) [Nigeria] and ICF International, 2013; Steptoe, Deaton, \& Stone, 2015). 
The study by Glascock (1980) indicated that, in order to understand the definition of old age in Africa, three aspects are to be captured. The first is chronology referring to number of years spent from birth. Secondly changes in social role and transformations in ability to work such as retirement, passage into higher adult status indicated by having children and menopause in the female gender. Thirdly, transformations in capabilities relating to invalidity in social functioning, becoming senile and the transformation of physical characteristics in an individual (Shofoyeke \& Amosun, 2014).

Bensaid \& Grine, (2014), pointed that, the Islamic definition of old age indicates the age of forty as a time of maturity and wisdom. It was at this age that Prophet Muhammad (SAW) is reported to have received the revelation of the Qur'an. In Islamic literature, there are concepts that can relay both time and socially constructed meanings of old age. The Young old is a person aged 60 and 75, who is still active socially. The "Sheikh" refers to an old man of 75 to 85 who is less active socially. The "Haarm" is a much older person of 85 years or who is more restricted by frailty. Finally, the centenarian known as "Al-Moamer" who is 100 years or more. Therefore, due to variations in the way ageing occurs across cultures, old age should be understood with important cultural variations.(Bensaid \& Grine, 2014; Helliwell, Layard, \& Sachs, 2012; Kinsella \& Phillips, 2005; United Nations Population Fund (UNFPA) \& and HelpAge Internationa, 2012)

\section{Death}

Death refers to the end of life. The cessation of life, implying the permanent cessation of all vital bodily functions. The legal standards for determining death are; the total cessation in vital functions of the body, usually demonstrated by "an absence of spontaneous respiratory and cardiac functions". In order words when "An individual who has sustained either (1) irreversible cessation of circulatory and respiratory functions, or (2) irreversible cessation of all functions of the entire brain, including the brain stem is dead". (American Medical Association in 1980 and American Bar Association in 1981).

The commencement of death begins when death as a fact of life becomes finally recognized, communicated and accepted (Kastenbaum Columbus Charles E, 1986). Older adults, finally recognizes that, their death is close. In later life, older adults have the tendency to think more about death, more than other age groups (Blesky J, 1990). In later life, the fear of death seems the most prevalent emotion. (Feifel H, Branscomb AB: 1973). Other states related to Death are anxiety, forgiveness, hope and the continuity of hope, loneliness, dignity/integrity the feeling of loss (Feifel, 1977; Fischer, 1998; Johnson, \& 2005; social \& 1985; Thibault, Care, \& 1993)iles must be in MS Word only and should be formatted for direct printing, using the CRC MS Word provided. Figures and tables should be embedded and not supplied separately.

\subsection{Literature Review}

A Spirituality has been recognized as crucial in ensuring positive outcomes for the psychological and physical well-being in later life (Armstrong et al., 2002;Pickard \& Nelson-Becker, 2011; Puchalski et al., 2009 ; Niederman, 1999 ; Seicol, 2005). Through Spirituality fundamental issues like deficits of inner faith, restoration of personal worth and significances, mortality, recognition of the existence of a higher power, and the definitive meaning of life, can be addressed in old adults(Canda \& Furman, 2010; Edwards, 2002; of \& 1998, n.d.; P. S.-S. Work \& 1994).

Like spirituality, religion plays an important role in the lives of older adults. The reason being that, within the natural process of aging, a foreseeable end to an individual's life becomes evident. This followed by a context where older adults can become more self-reflexive and self-accepting. Thus, opening the mind/body/spirit to include the need for an expansion in mind activities towards a quest for deeper sense of knowing, thereby given prominence to the spiritual dimension(Atchley, R. C., \& Barusch, 2000; M., 2009; McFadden, 2005; Moberg, 2005; Tornstam, 2005).

Finding meaning and purpose through spirituality has been recognized by several authors as important for older adults (Birkenmaier, Behrman, \& Berg-Weger, 2005). Consequently, spirituality in older adults has been seen as a positive factor, especially in relation to their state of emotion, mentality, and physical happiness.

It has been suggested that, improvement and intensification of spiritual development is more common in later stages of adulthood. The reason being that, individuals are more likely to engage in advance exploration about both meaning of their life and reasons for their existence. Furthermore later life is accompanied by relevant changes in role, social status and personal identity, the need to cope with an illness, recover from the loss of loved ones, and coping with limitations posed by old age(Armstrong et al., n.d.; Barik et al., 2015; D. M.-J. of G. S. Work \& 2005). Among a significant number of older adults, spirituality evolves in late life because of their lifetime commitment in spiritual/religious beliefs. While in others it emerges newly based on late life experiences (Africa \& 1996, n.d.; Eisenhandler, 2005; Lewis-Williams, D. J., \& Pearce, 2004). The importance of spiritual needs has been noted to emerge in the later life due to the need for avenue through which an individual seeks for forgiveness, and a perfect relationship with the sacred(Health \& 1991, n.d.; Staude, 2005; Steinhauser et al., 2008). I 
The meaning of existence among Muslims in this world is that of a brief stopover, while the final destination will be determined by Allah on the basis of one's deeds. Therefore, spirituality in Islam differs in conception to the secular understanding. Spirituality in Islam is rooted in the Qur'an, Sunnah, and absolute monotheism. The nature of spirituality in Islam makes it difficult to conceive of a Muslim as being spiritual without being religious. (Ahmad, 2015).

\section{Gender and Spirituality in Late Life}

From a gendered perspective, women seem to be more collective in practices related to spirituality then men. A contrary position by Learn, (1996), however, explained women's spirituality in later life as arising from a life of quilt. This explanation suggests that women join collective search for the sacred only to create a spiritual identity in old age. Despite this contrary position, Vahia et al.,( 2011). found that spirituality was an important factor for women in supporting resilience to stress in older adulthood (Hunter-Hernández, Costas-Muñíz, \& Gany, 2015 ; Foley , 2000). Similarly, Among African-American women, during old age, spirituality was important for the management of chronic illness ( Foley \& Hoge, 2007). Therefore, spirituality and religion are more than mere constructs for women. Furthermore, Spirituality affords women connections and meaning to existence in the world. (Susan H. McFadden, 2005)

\subsection{Theoretical Framework}

The study reviews a number of theories that have explained the reasons and out comes associated with increase spiritual activities in later life.

\section{Socioemotional selectivity theory}

This theory proposes that due to an intensification of emphasis upon emotion-related goals in later life, most individuals tend to be more aware of the shortness of life.(Carstensen, psychologist, \& 1999). Therefore, the increase in spiritual goals, and religious practices, stems from an increase in self-examination, as a natural part of the maturational process in both mid and later life.

\section{Disengagement theory}

Disengagement theory is a framework that explains the process of disengagement from active social life. In this theory, over time, elderly people disengage from active social roles, to a much narrower form of relationships, than was the case during their adulthood. As a functionalist theory, this framework depicts the process of disengagement as vital to the social system, as it allows the social system to remain more stable and ordered. This achieved through the disengagement of older adults and their replacement with the younger ones. Spiritual engagements are therefore escape outlets, arising from the harsh experience of disengagement. This theory is also inadequate in non-industrial societies, and societies where religious practices form the background of the social order.

\section{Continuity theory}

The basis for our analysis is Atchley's continuity theory, which assumes that individuals develop preferences as a part of their personality and, as they grow old, they continue in their spiritual tradition. The theory also considered the role spiritual beliefs and practices play in coping with the problems of later life, especially with regard to the experience of death. From the perspective of continuity theory, spirituality and religion provides a conceptual framework in later life for individuals to make sense of their past experience in the midst of change. (Atchley, 1997).

These values in Religious, spiritual, and personal worldviews, form part of the inner structure that persistently provide the older adult with a sense of identity and continuity. With the progression in age, the continuity of spiritual identity also increases as an important developmental task. Therefore, older adults adapt to this developmental task though religious beliefs and symbols as an anchor for coping with the changes that accompany aging. This serves as a potent source of meaning against immortality, the existence of heaven, and serves as an effective antidote to death anxiety (Wong, Reker, \& Gesser, 1994). Under the experiences and circumstances of later life, religion provides both direction and support for conceiving life and death (Caldas et al., 2015; the \& 1985.; Values, ethics, Lesnoff, \& 1985 ; Wong, Reker, \& 1994 ; Yip, 2011).

\subsection{Material and Methods}

Study site and Subjects

The study was conducted in Bauchi Emirate Council which was founded by Fula in the early 19th century. The Emirate was formally under the British Protectorate during the colonial era. The Emirate is located in the present day Bauchi State, Nigeria. It covers an area of 3,687 km2 and had a population of 493,810 at the time of the 2006 Census. The population of the study comprised of elderly women Jeedo adherents in Bauchi Emirate Council and major stakeholders that influences the practice such as the Emirate Council members, community leaders and relevant partners to the Jeedo practice among the clergy. 


\section{Sampling Procedure}

The Purposive sampling technique was employed in selecting respondents for the study. The sample comprised of one (1) History Officer (Wakilin Tarihi), One (1) Jeedo leader, fourteen (14) High Council members of the Jeedo, four (4) Emirate Historians, seven (7) Focus Group Participants, and five (5) Clergy. Within the Jeedo participants, participation was done within the core 70 congregational member at major session's activities while 32 were interviewed according to their convenience. The FGD participants were identified with assistance of the Mosque administration and the History Officer (Wakilin Tarihi). The FGD sessions with Jeedo members were conducted after obtaining permission from the Jeedo leader.

\section{Methods of Data Collection}

The data were collected through Participants Observation, Interview and Focus Group Discussion (FGD). The rationale behind choosing participatory is because it relates to the nature of the research problem; it is appropriate for the investigation of practices that affects people's lives. It is also associated with finding the nature or meaning of human experience which guides the research philosophy. It is also good for participatory field investigation to get complex information which is in line with suggestions of Strauss (Chamberlain-Salaun, Mills, \& Usher, 2013; Dankl, 2017; Holkup, Tripp-Reimer, Salois, \& Weinert, 2004).

Therefore, the focus was on the subjective meanings attached to spirituality and religion in Jeedo practices, old age and the experiences which give meaning to life as a Jeedo adherent. In relation wellbeing. The research relied as much as possible on learning from the participants. The aim was to explore the implied meaning of spirituality and religion in the Jeedo both historically, and practically within specific contexts in which the Jeedo is practiced. The Researchers sought to establish the meaning of spirituality and religion in the Jeedo from the views of participants. This meant identifying how the adherents shared the views and practices about the Jeedo as an aspect of the religious culture in Bauchi emirate. The key elements used in this approach were the collection of data through participation and observing the elderly and their spiritual and religious activities in the Jeedo.

This research comprised of a range of methodological approaches and techniques based on the participatory research design. Collaboration and consultation of participants in the Jeedo as group, was the main approach. The aim remained an in-depth understanding of spirituality and the improvement of the Jeedo practice in relation to the wellbeing of the elderly women. The traditional notion of reducing bias and Researchers influence was eliminated and instead, a recognition that individual assumptions shaped how the Researchers perceived the Jeedo practice as social reality. Much was achieved by allowing an emergent research form which participants shaped the form and nature of the enquiry.

The role of the researchers were to act as a participants, interviewers, observers and analyzers; in other words, the researchers participated on the activities of the group, interviewed the selected members of the group, and at the same time, pictures of the observed phenomenon under investigation were taken. Finally, the Researchers took his time to analyses the phenomenon.

Interviews, focus groups, participatory inquiry were employed where and when applicable at different stages of the research to ensure reflexivity. What is important in participatory research is not the methods, but the methodological contexts of their application. As such the key element of participatory research lies not in methods but in the attitudes of Researchers, which in turn determines how, by and for whom research is conceptualized and conducted. To comply with this principle, the location of power in the various stages of the research process was much as possible with the participants. (Cornwall, A., \& Jewkes, R. 1995).

This Participatory research is theoretically situated at the collegiate and consultative levels of participation (Cornwall, \& Jewkes , 1995). From the four modes of participation identified by Biggs the combination of consultative and the collegiate approaches to participation were adopted by the research. The participants were asked for their opinions and were actively consulted by researchers and the researchers also worked together as colleagues in a process of mutual learning about the Jeedo practice

\subsection{Results}

Table 1 reveals the findings on Jeedo practice as bases for spiritualty and religion among elderly women in Bauchi Emirate Council. The findings were presented in accordance with the themes and sub-themes of the study.

Table 1 : Spirituality and religion in Jeedo Practice among Elderly Women in Bauchi Emirate Council.

\begin{tabular}{|c|c|c|}
\hline Theme & Subtheme & Findings \\
\hline Bases For & Spirit Of Jeedo & \multicolumn{1}{|c|}{ "To start with the word Jeedo unlike the pronunciation by } \\
$\begin{array}{c}\text { Spiritualty And } \\
\text { Religion In The } \\
\text { Jeedo Practice }\end{array}$ & & $\begin{array}{l}\text { most people around as Jeedo" should be understood from its Hausa } \\
\text { meaning which means Jeedo i.e. transferring an object from one } \\
\text { place to another. For example, ants can come out in millions to }\end{array}$ \\
\hline
\end{tabular}




\begin{tabular}{|c|c|c|}
\hline & & $\begin{array}{l}\text { transfer the contents of a barn to its nest by gradually picking one } \\
\text { grain after the other until the whole barn is emptied. Such cannot } \\
\text { be accomplished by a single insect but because of team work and } \\
\text { the spirit of oneness the ant or bees are able to accomplish that } \\
\text { much within a night or even a shorter period. This literally } \\
\text { describes the basis of the word Jeedo as a Hausa word implying } \\
\text { the transfer of large number of items from one point to another } \\
\text { through team work. Such team work activity is called Jeedo }\end{array}$ \\
\hline & $\begin{array}{c}\text { Spiritual } \\
\text { Attachment To } \\
\text { The Practice }\end{array}$ & $\begin{array}{l}\text { "The building of the old mosque in Bauchi was also central to } \\
\text { the introduction of the Jeedo practice and the eventual } \\
\text { institutionalization of the practice. As noted by the emirate } \\
\text { historian (Wakilin Tarihi) } \\
\text { the Jeedo practice began when Mallam Yakubu was building } \\
\text { the Bauchi central mosque when he was building Bauchi, because } \\
\text { actually he did not reside initially in present Bauchi, he was } \\
\text { building the town from his base in kilometer which not more } 3 \\
\text { kilometers from Bauchi. It was where Mallam Yakubu operated it } \\
\text { is now where the railway crosses around military road block. } \\
\text { Around } 1807 \text {-1808, (OR3- history officer) } \\
\text { Mallam Yakubu actually established the foundation of Bauchi } \\
\text { around } 1809 \text { and the first project to be executed by Mallam } \\
\text { Yakubu is the Bauchi mosque which stands right outside the } \\
\text { palace you need snap the pictures to verify what I am telling you } \\
\text { since the structure is there. So, the mosque was built. The emir } \\
\text { then appoints the Jeedo to maintain the new mosque } \\
\text { "The practice is related to Ummu Sauda also known as Ummu } \\
\text { Mihjan. A black woman who sweeps the mosques regularly. But } \\
\text { was not seen after a while by the prophet. He asked and was told } \\
\text { that she has died. The prophet asks why he was not told and } \\
\text { commanded to be shown hear grave which he went and prayed for } \\
\text { her (OR6- Jeedo Leader). }\end{array}$ \\
\hline $\begin{array}{l}\text { Modelling Of } \\
\text { Pious Women }\end{array}$ & Maryam(As) & $\begin{array}{l}\text { In the history of prophet Musa (AS), Ali-Imran was the } \\
\text { custodian of Beitul Muqaddas, there is a woman daughter of Ali } \\
\text { Imran mother of Maryam who promised that whatever she gave } \\
\text { birth to will be dedicated to service of the mosque. This includes } \\
\text { washing cleaning and fetching water for rituals. When she gave } \\
\text { birth to Maryam the promised of dedicating Maryam to the service } \\
\text { of the mosque was fulfilled and that is to be seen as the origin of } \\
\text { the Jeedo practice from Islamic literature (OR6-Jeedo school } \\
\text { teacher) } \\
\text { It began with the history of Maryam (AS) in relation Ali } \\
\text { Imran, instead of given him a son Allah gave him a female. She } \\
\text { has not been on menstrual period neither did she ever seen a man. } \\
\text { She is fed from Janna for working in the mosque. It also for } \\
\text { working in the mosque that she was rewarded with Isa (AS). When } \\
\text { people ask her how born a child without a father, she was ordered } \\
\text { by Allah to allow the son to reply. For every enquiry he replies and } \\
\text { they became convinced while some were misled into believing that } \\
\text { he the son of God because of His miracle power (OR6-FGD 1) } \\
\text { We believe in serving the cause of Islam through various } \\
\text { engagements in the Jeedo practice based on the perception that at } \\
\text { this point of old age, this way we derive satisfaction that we are } \\
\text { worshipping to be rewarded late when we die. It a kind of } \\
\text { preparation for dying }\end{array}$ \\
\hline Rituals In Jeedo & & Fasting Monday and Thursday \\
\hline
\end{tabular}




\begin{tabular}{|c|c|c|}
\hline Practice & $\begin{array}{l}\text { Rituals And } \\
\text { Routine }\end{array}$ & $\begin{array}{l}\text { - Daily Islamic teaching } \\
\text { - Assignment of Nafila } \\
\text { - Assignment of zikr } \\
\text { - Quranic recitation on Thursday as required by the Jeedo } \\
\text { (complete) } \\
\text { - Caring for the members in preparation towards their final } \\
\text { transition } \\
\text { - Visit to the sick members } \\
\text { - Submission of prayers requests to people embarking on hajj } \\
\text { - Sweeping and cleaning of the mosque } \\
\text { - Cleaning of grave yards and Eid ground } \\
\text { - Janaiza" Cremation of destitute women } \\
\text { Suratul Amma to Fatiha } \\
\text { Individual Tasbih suratul mulk we recite depending on how } \\
\text { we are requested (1000) All of us in Jeedo does that any amount. } \\
\text { then we share istighfar is shared weekly on Thursdays to be done } \\
\text { through the week } \\
\text { Zikr supplication to Allah and praise to the Prophet } \\
\text { Muhammad (SAW Subhanaka gainaka indallah Laila hazbuka } \\
\text { nurullah praise to Allah and the prophet } \\
\text { 'Subhaanaka Allaahumma wa bihamdik, Ash-hadu allaa } \\
\text { ilaaha illaa ant, Astaghfiruka wa atoobu ilayk, } \\
\quad \text { La ilaha illallahu wahdahu la shareeka lahu, lahul-mulku wa } \\
\text { lahul-hamdu wa huwa ala kulli shai in qadeer' } \\
\text { Allahumma anta Rabbi la ilaha illa anta, Anta Khalaqtani wa } \\
\text { ana abduka, wa ana 'ala ahdika wa wa'dika mastata'tu, A'udhu bika } \\
\text { min Sharri ma sana'tu, abu'u Laka bini'matika 'alaiya, wa Abu } \\
\text { Laka bidhanbi faghfirli innahu la yaghfiru adhdhunuba illa anta } \\
\text { La hawla wala quwawata illa billah } \\
\text { HasbunAllahi Wani'mal wakeelAllahumma salli ala } \\
\text { Muhammad, Wa ala ali Muhammad, Kama sallayta ala Ibrahim, } \\
\text { Wa ala ali Ibrahim, Innaka hamidun majidAllahumma Barik ala } \\
\text { Muhammad Wa ala ali Muhammad Kama, barakta ala Ibrahim, } \\
\text { Wa ala ali Ibrahim Innaka hamidun majid }\end{array}$ \\
\hline Ritual Schedules & & $\begin{array}{l}\text { Daily we gather to do zikir iafter subhi prayer Sometimes we } \\
\text { pray in Jeedo house, } \\
\text { Within the week, day and night we are engaged in one activity } \\
\text { or the order, Thursday; afternoon is only to preach by guests ustaz, } \\
\text { Thursday; early morning we recite the Quran. We dedicate } \\
\text { this day for prayers where we shared the Quran into } 1010 \text { chapters } \\
\text { to each member then we recite and compile the number of } \\
\text { recitations after wards. . } \\
\text { Annually; In a year we have important dates like } 158 \text { and } 27^{\text {th }} \\
\text { of Ramadan. After Ramadan we observe sitta shawwal. } \\
\text { Rajab is important to us. During the Rajab we are also busy in } \\
\text { devotion. }\end{array}$ \\
\hline
\end{tabular}

\subsection{Discussion}

Bases for Spiritualty and Religion in the Jeedo Practice

As evident from the data, a spirit of diligence and active duty exist among the Jeedo members. The meaning of the word Jeedo from its Hausa translation, refers to a spirit of labor and diligence. In practice, Jeedo is the transfer of objects from one place to another, best exemplified by the activities of termites, bees or similar insects that move items from one point to another, with perseverance and diligence. For example, ants can come out in millions to transfer the contents of a barn to its nest. The ants gradually pick one grain after the other, until the whole barn is emptied. This literally reflects the active spirit, with which the Jeedo is practiced. Through similar diligence, the Jeedo practice keeps the adherents in activity. Different religious tasks are performed under the instruction of the "Jeedo". 
Although the main motive is to die in grace, various factors are responsible for pushing the adherents into the Jeedo. Reasons given include problems associated with later stages of adulthood like changes in role status and identity, such as disengagement from active social process due to old age, the need to cope with illness and at the same time die in grace. Others join the Jeedo, due to the need for devotional education provided on daily basis, access to the mosque premises for prayers, finding company of others, prayer for the children to be left behind, prayer for peace in one's grave, prayer for an easy end of life, seeking forgiveness and assistance to cope with daily limitations .

\section{Modelling of pious women \\ Umm Sauda}

From most of account obtained from community participants, the history of Umm (Suda) Mihjan influences the Jeedo practice. this account relates how a black African woman was so endeared to the Prophet (SA), that he went to her grave and prayed for her, with the assurance that, she is in paradise for sweeping the mosque (The Pen Publishers 2015). From this teaching, the Jeedo adherents do not compromise any bit of act that will add to their devotion in the mosque maintenance. Examples like that of Umm Mihjan makes the adherents more committed to the Jeedo. This creates further sense of attachment to the Jeedo, as the adherents are constantly in touch with another waiting to be assigned any task in the mosque.

\section{Sayyida Maryam}

Another influence that has been the basis of the Jeedo from all the accounts, is Sayyida Maryam (AS), based on the meaning of Jeedo, derived through the history of prophet Musa (AS), and "Ali Imran". All the adherents hope to be rewarded by Allah like the promised fulfilled to the mother of Maryam (AS). For dedicating her daughter (Maryam) to the service of the Mosque. For this act, Allah blessed and rewarded Maryam (AS) with prophet Isa as a son (AS). This exerts tremendous influences on the Jeedo and it is always a point of reference in what they do.

\section{Nana Asmau}

Nana Asmau and her disciples (iyanTaru) also influences the Jeedo. Nana Asmau was a famous female scholar and direct descendant of the Caliph Usman bin Fodio. She was a famous and her prominence came to lime light when the death of the caliph created an intellectual vacuum for a high caliber scholar. She led the way for women in the caliphate by continuing with the tradition of teaching both men and women as started by the Shehu.

Her famous class of female students known as "iyan taru" (female congregation of matured scholars) were thought Islamic lessons. They were women who are beyond school. Out of the iyantaru, more senior ones were selected among those in menopause to engage in cleaning the mosque before each prayer. The old women also clean and supply water for prayers. This influenced the establishment of the Jeedo in Bauchi, despite the differences in name and the advance nature of the practice, as Jeedo in Bauchi Emirate. The link to the Jeedo from Sokoto caliphate was possible through the contribution of Yaya, the wife of the founder of Bauchi, Mallam Yakubu. She was a grand-daughter of the caliph Usman bin Fodio. While marrying the emir of Bauchi, she maintains regular correspondence with Nanan Asmau. This greatly influence the practice of giving women education by Yaya, who was said to have contributed greatly in the establishment of the Jeedo in the old mosque in addition to the authority of the emir.

\section{Rituals, Recitations and Schedules}

Rituals

The core activity of the Jeedo is Sweeping and cleaning of the mosque. Every Friday, the Jummat Mosque is swept according the portions assigned to each member by the Jeedo. This is done based on rank in the Jeedo hierarchy. The higher-ranking members are assigned inner chambers of the chief Imam, and the emir's portion. The allocation of potion extends out wards up to the last ranks that attends to the toilets. The Cleaning of grave yards and Eid ground are also shared in a similar manner. Nafilas are performed in the mosque after sweeping every Friday. All the Nafilas are contained in a book that is possessed by each member.

Activities are assigned on daily and weekly bases. This is done by the Jeedo and the priests (ustaz) under the Jeedo. The priests are both male and female. Prayers assigned include; fasting, (nafila) on Monday and Thursday, individual Tasbih depending on the number and type requested from an adherent (from 1000 to any amount). Weekly prayer for forgiveness (Itstigfar), offered from Thursdays through the week.

Daily Islamic teaching of Quran and exigencies, are conducted by the teachers covering subjects like Fiqhu, Tajweed. Quranic recitation is undertaken daily, according to various grades. Other books covered are Qawaidi. Prayer requests of adherents are submitted to persons that are to recently embark on hajj or umrah to the holy land of Mecca and Medina as last wish of most adherents.

When a member is over whelmed by sickness, the Jeedo is notified. Special attention and Caring through intensive prayer and medical attention. Such members are always accompanied by a member or two in preparation towards their final transition. Visit is without limits and the Jeedo visits at regular intervals. Cremation of destitute women are daily activities of the members. 


\section{Recitations}

On the way to the mosque, every Friday, they Jeedo adherents chant songs of praise (to Allah, the Prophet (saw) and the Jeedo). Similarly, on the way to the Eid prayer, this old version is recited "Subhanaka gainaka indallah Laila hazbuka nurullah". Presently the singer sings according the situation prevailing, for example during Ramadan the songs differ from ordinary days.

To seek forgiveness for sins, the recitation, is 'Subhaanaka Allaahumma wa bihamdik, Ash-hadu allaa ilaaha illaa ant, Astaghfiruka wa atoobu ilayk,' meaning: O Allah, You are free from every imperfection; praise be to You. I testify that there is none truly worthy of worship except You; I ask Your forgiveness and turn to You in repentance, times.

To be shield from Satan in old age the recitation is 'La ilaha illallahu wahdahu la shareeka lahu, lahul-mulku wa lahul-hamdu wa huwa ala kulli shai in qadeer', The meaning of this Kalima is: "None has the right to be worshipped but Allah (Alone) Who has no partner; to Him belongs the kingdom (of the universe), and for Him are all the praises, and He has the power to do everything. The recitation is 100 times.

For protection and to avoid fitna in duniya and akhira the prayer recited is Allahumma anta Rabbi la ilaha illa anta, Anta Khalaqtani wa ana abduka, wa ana 'ala ahdika wa wa'dika mastata'tu, A'udhu bika min Sharri ma sana'tu, abu'u Laka bini'matika 'alaiya, wa Abu Laka bidhanbi faghfirli innahu la yaghfiru adhdhunuba illa. meaning O Allah! You are my Lord! None has the right to be worshipped but You. You created me and I am Your slave, and I am faithful to my covenant and my promise as much as I can. I seek refuge with You from all the evil I have done. I acknowledge before You all the blessings You have bestowed upon me, and I confess to You all my sins. So I entreat You to forgive my sins, for nobody can forgive sins except You. This recited 100 time.

Another recitation is La hawla wala quwawata illa billah ; meaning there is neither power nor ability save by Allah. And to leave all affairs to Allah: the recitation is HasbunAllahi Wani'mal wakeel Allah (alone) is sufficient for us (Qur'an 3:173) By leaving your affairs to Allah, by depending upon Him, by trusting in His promise, by being pleased with His decree, by thinking favorably of Him, and by waiting patiently for His help, you reap some of the greater fruits of faith and display the more prominent characteristics of the believer.

Other recitations frequented by the Jeedo adherents are ; Allahumma salli ala Muhammad, Wa ala ali Muhammad, Kama sallayta ala Ibrahim, Wa ala ali Ibrahim, Innaka hamidun majidAllahumma Barik ala Muhammad Wa ala ali Muhammad Kama, barakta ala Ibrahim, Wa ala ali Ibrahim Innaka hamidun majid. Meaning: O Allah, send prayers on Muhammad and on the family of Muhammad, as You sent prayers upon Ibrahim and on the family of Ibrahim You are indeed worthy of Praise full of Glory.O Allah, send blessings on Muhammad and on the family of Muhammad as You sent blessings upon Ibrahim and on the family of Abraham You are indeed worthy of Praise, full of Glory.

Bismillahillazi la yadurru ma'asmihi syaiun fil ardi wa la fis sma'ie, wahuwas sami'ul 'alim. Bismillahillazi la yadurru ma'asmihi syaiun fil ardi wa la fis sma'ie, wahuwas sami'ul'alim. Which means: In the name of Allah which has not been condemned by His name on earth and in the heavens, and He has heard and knows

The three Qur'anic Chapters frequently recited by individuals in the Jeedo are Suratul Amma to Fatigha every day, Mulk Falq and Nas. The objective of reciting these verses is for protection.

Important schedules

The month of Rajab is important to the Jeedo practice. During this period, the members are more occupied in devotion. Throughout the month, a total of 3,334 units of prayer circles (Rakats) are performed in the month. In addition to Ramadan Prayers (Salat al Tarawih). In addition, other supplication and extra devotional prayers (Nafila), were performed according to the ability of a member.

During the month of Rajab, each member performs 4 unit circles of prayer (Rakaat) each is accompanied by 300 repetitive utterances of praise and glorification of Allah (Tashbihs)

Monday and Thursdays, are for fasting. The most important day is Friday. Gathering is compulsory unless one is sick, Thursdays are dedicated for prayers, where 10 chapters (Hizbs)are share to each member. After recitation the results are compiled on the next Thursday. Usually on Thursdays, there is no sweeping. The only activity is preaching by guests and the Jeedo teacher ( ustaz).

Within the Important dates in Jeedo practice, the period of Ramadan appears to be most busy in terms of devotion. From the opening of the tafseer on the 1s of Ramadan, activities are designed to engage all members from dawn to dusk ( subhi to asar prayes). The routine for the period of Ramadan are; arrival at the mosque very early in the morning to listen to the dalalani, followed by the offer of prayers in the Jeedo chambers and conducting social work-related activities. Paying attention to any issue arising from reports within the emirate, especially where the attention of the Jeedo is needed. Such as bereavement and loss of children or as the case may be.

By the 15th day of Ramadan prayers are offered by the Jeedo. On this day the whole congregation and other elderly women are invited from across the emirate to attend the 15th day Ramadan congregation (adduan sha biyar). It is quite an elaborate occasion. Similarly, on the 8th day of Ramadan, another prayer is offered by the Jeedo, in the spirit of the Ramadan. Finally for the Ramadan period, the 27 th day is very important for the Jeedo, as it marks the end of the blessed month of Ramadan which most members assume may be their last on earth. Therefore, the spirit of devotion and line of activities are very tedious on this day. Then Sitta shawwal and Fasting every Monday and Thursday, in addition to compulsory Quran recitation every day of the week throughout the year. 


\section{Spirituality, religion and dying in the Jeedo practice}

Spirituality in the Jeedo is evident from the reasons given for joining the practice. Most of the elderly women join the Jeedo practice for opportunities towards higher engagement in devotion, and activities that imply a good end to their lives. This serves as the most important reasons for joining the practice (Birkenmaier, Behrman, \& Berg-Weger, 2005). From the data, all the participants in the Jeedo believe that, they are at the end of the aging process, and death is a foreseeable end that will soon be experienced. As such, a deeper sense of commitment to devotion is a prominent activity (Atchley, 2000; McFadden, 2005). (Johnson, 2009; Moberg, 2005; Tornstam, 2005).

To attain spirituality, the practice utilizes religion as a systematic guide, through scheduled activities, shared by the adherents, as a moral community. This is done through the religious hierarchy of the Jeedo in a formalized manner. Through the hierarchy, rituals are assigned and coordinated. Findings also revealed that, devotional activities are the means through which spiritual attachment and fulfillment to the Jeedo tends to be upheld. (Cornett, 1992; NelsonBecker, et al., 2007; Sermabeikian, 1994). Therefore, spirituality in the Jeedo manifest trough a pattern of religious behaviors, orientated toward the preparation for a better afterlife (Canda \& Furman, 1999,).

A significant number of the adherents had a life time of spiritual and religious commitment, which according to some has even diminished, because they are not as strong as before. For others the Jeedo as a spiritual religious practice, is a theme that evolved in the later parts of their lives, due to regret over the past deeds (Learn (1996), diseases, and ultimately, the need to die in grace. Eisenhandler (2005). (Sacco, 1996; Williams, 2004). (Armstrong, \& Crowther, 2002; Nelson-Becker, Nakashima, \& Canda, 2007; Niederman, 1999; Seicol, 2005).

Most participants testified to higher Spiritual experience, morality and a better feeling of self-worth. Furthermore, they now feel better inner faith and personal link to God, hoping to meet the end in grace. (Cascio,1998; Canda \& Furman 1999; Edwards, 2002; Sermabeikian,1994).

\subsection{Conclusion}

Within the Islamic perspectives of spirituality and religion, the Jeedo share similarity with examples like suluk and Pondok among others. The Jeedo shares similarity to other systems religious engagement in the religious and spiritual engagement of elderly people. Similar to "Suluk" which literally means take a path or road, the Jeedo in relation to the religion of Islam and Sufism, also means the path of spirituality through diligence. This creates a feeling of being on right path leading to a perfect relationship with Allah, in form of Recourse (bersuluk). However, while the suluk includes a lifelong discipline in abiding by the Shari'a and esoteric Islamic explanations of nature and the way things occur, the Jeedo steps ahead as preparation for death.

Like the word "salik" which comes from the terminology of the Qur'an, Fasluki, meaning Someone who took the road, usually associated with Sufism, the word Jeedo comes from the literal perception of the works of Sayyida Maryam (AS) based on her zeal and commitment to duty in the Mosque and the service of Allah. This made the Jeedo adherents similar to the a salik as someone who undergoes a spiritual discipline to cleanse and purify the soul. Again, the motive is similar, since for the Jeedo also the goal is to pave the way for death in faith "iman". Therefore, the totality of the Jeedo practice means to constantly keep the parts of the body and the heart occupied in the obedience of Allah Most High. These include all the activities and duties of the congregation and the core 70, in addition to the wider Jeedo network.

Another practice is referred to as the Pondok system which shares similarity also in the aspect of spirituality and a platform for devotion. Similar to the Jeedo, with regard to education, the 'Pondok' originated mainly as' Religious schools among the Malay ethnic group. (Khoo, 1991). Similarly, the account of nana Asama'u indicates educational services by elderly women as the origin of the Jeedo from the caliphate both were therefore, inspired by the spread of Islam.

Similar to the Pondok, the Jeedo as well provides a bases for Islamic Education, and means for spending old age in spiritual devotion. It is similarly a way to seek for continual religious education. In addition, both systems regard, Spiritual well-being of the elderly as the main goal. (Sufian and Mohamad, 2013).

\section{References}

Africa, T. S.-J. of S. D. in, \& 1996, undefined. (n.d.). Spirituality and social work students in their first year of study at a South African university. Sanweb.lib.msu.edu. http://sanweb.lib.msu.edu/DMC/AfricanJournals/pdfs/social development/vol11no2/jsda011002006.pdf

Ahmad, M. (2015). A Model of Spirituality for Ageing Muslims. J Relig Health. https://doi.org/10.1007/s10943-0150039-0 
Ai, A. L., Peterson, C., \& Huang, B. (2003). Research: The Effect of Religious-Spiritual Coping on Positive Attitudes of Adult Muslim Refugees From Kosovo and Bosnia. International Journal for the Psychology of Religion, 13(1), 2947. https://doi.org/10.1207/S15327582IJPR1301_04

Allport, G., psychology, J. R.-J. of personality and social, \& 1967, undefined. (n.d.). Personal religious orientation and prejudice. Psycnet.apa.org. Retrieved from http://psycnet.apa.org/journals/psp/5/4/432/

Armstrong, T., Development, M. C.-J. of A., \& 2002, undefined. (n.d.). Spirituality among older African Americans. Springer. Retrieved from http://www.springerlink.com/index/J8J6347350V62872.pdf

Atchley, R. C., \& Barusch, A. S. (2000). Social forces and ageing: An introduction to social gerontology. Wadsworth, Belmont, CA.

Babatunji, A. O., Shuaibu, J. Y., Zara, W., Mary, O. A., John, S. B., \& Jasper, U. (2015). Assessment of the determinants of healthy ageing among the rural elderly of north-eastern nigeria. Health, 7(June), 754-764. https://doi.org/10.4236/health.2015.76090

Baker, T. A., Buchanan, N. T., Mingo, C. A., Roker, R., Brown, C. S., Med, M., \& Bowers, B. J. (2015). Reconceptualizing Successful Aging Among Black Women and the Relevance of the Strong Black Woman Archetype, 55(1), 51-57. https://doi.org/10.1093/geront/gnu105

Barik, D., Council, N., Desai, S., Management, F., Zielinski, A., Halling, A., ... World Health Organization. (2015). Managing the Care of Patients With Diabetes in the Home Care Setting. Diabetes Spectrum, 2(1), $162-166$. https://doi.org/10.1016/S0140-6736(10)61188-9

Beckford, J., \& Demerath, J. (2007). The SAGE handbook of the sociology of religion. Retrieved from https://books.google.com/books?hl=en\&lr=\&id=vA8edg7bv0kC\&oi=fnd\&pg=PR5\&dq=Beckford,+J.+\%26+Demerath ,+N.J.+(2007)+The+Sage+Handbook+of+Sociology+of+Religion.+London:+\%09Sage.++\&ots=EtjoSZA8aX\&sig=_qi 9w3-oK_SNuxdRGZF4fFL35hU

Bensaid, B., \& Grine, F. (2014). Old Age and Elderly Care: An Islamic Perspective. Cultura. Retrieved from http://www.ingentaconnect.com/content/plg/cultura/2014/00000011/00000001/art00009

Berkel, L. A., Armstrong, T. D., \& Cokley, K. O. (2004). Similarities and Differences Between Religiosity and Spirituality in African American College Students: A Preliminary Investigation. Counseling and Values, 49(1), 2-14. https://doi.org/10.1002/j.2161-007X.2004.tb00248.x

Birkenmaier, J., Behrman, G., \& Berg-Weger, M. (2005). Integrating Curriculum and Practice with Students and their Field Supervisors: Reflections on Spirituality and the Aging (Rosa) Model. Educational Gerontology, 31(10), 745-763. https://doi.org/10.1080/03601270500250150

Caldas, C. P., Gordilho, A., Nascimento, J. S., Silvestre, J., Ramos, L. R., Freire, M. P. a., ... Carvalho, J. A. (2015). The Mental Health Needs of an Aging Population Prepared by: David Whalen, B . A . for the. Memória e demência:(re)conhecimento e cuidado (Vol. 23). https://doi.org/10.2765/76255

Canda, E., \& Furman, L. (2010). Spiritual diversity in social work practice: The heart of helping. Retrieved from https://books.google.com/books?hl=en\&lr=\&id=XNkJB2HrWQ8C\&oi=fnd\&pg=PR13\&dq=Canda+\%26+Furman+199 9+spirituality\&ots=PyQfPbdAZV\&sig=PggI9_YboXU13-2ITB4SnofKeJw

Carstensen, L., psychologist, D. I.-A., \& 1999, undefined. (n.d.). Taking time seriously: A theory of socioemotional selectivity. Psycnet.apa.org. Retrieved from http://psycnet.apa.org/journals/amp/54/3/165/

Chamberlain-Salaun, J., Mills, J., \& Usher, K. (2013). Linking symbolic interactionism and grounded theory methods in a research design: from Corbin and Strauss' assumptions to action. SAGE Open. Retrieved from http://journals.sagepub.com/doi/abs/10.1177/2158244013505757

Collins, K. S., Furman, R., Hackman, R., Bender, K., \& Bruce, E. A. (2007). Tending the Soul: A Teaching Module for Increasing Student Sensitivity to the Spiritual Needs of Older Adults. Educational Gerontology, 33(9), 707-722. https://doi.org/10.1080/03601270701364420 
Cornwall, A., medicine, R. J.-S. science \&, \& 1995, undefined. (n.d.). What is participatory research? Elsevier. Retrieved from http://www.sciencedirect.com/science/article/pii/027795369500127S

Dankl, K. (2017). Design age: Towards a participatory transformation of images of ageing. Design Studies. Retrieved from http://www.sciencedirect.com/science/article/pii/S0142694X16300692

Edwards, W. (2002). Recovering spirit: Exploring aboriginal spirituality. Retrieved from https://scholar.google.com/scholar?hl=en\&as_sdt=0\%2C5\&q=Edwards\%2C+2002+spirituality\&btnG=

Eisenhandler, S. A. (2005). Religion is the Finding Thing. Journal of Gerontological Social Work, 45(1-2), 85-103. https://doi.org/10.1300/J083v45n01_06

Feifel, H. (1977). New meanings of death. Retrieved from http://psycnet.apa.org/psycinfo/1978-08140-000

Fischer, K. (1998). Winter grace: Spirituality and aging. Retrieved from https://scholar.google.com/scholar?hl=en\&as_sdt=0\%2C5\&q=Fischer+K\%3A+Winter+\%2C1998\&btnG=

Foley, M., \& Hoge, D. (2007). Religion and the new immigrants: How faith communities form our newest citizens. Retrieved

from https://books.google.com/books?hl=en\&lr=\&id=sN1OexlbZOgC\&oi=fnd\&pg=PR9\&dq=foley+2000+religion\%2Bwo men\&ots=btVMcftx-5\&sig=R2Rlei7pIUboIGr1uf0dTafix 28

Furman, L. D., Benson, P. W., Canda, E. R., \& Grimwood, C. (2005). A Comparative International Analysis of Religion and Spirituality in Social Work: A Survey of UK and US Social Workers. Social Work Education, 24(8), 813839. https://doi.org/10.1080/02615470500342132

Health, P. R.-F. \& C., \& 1991, undefined. (n.d.). Spirituality and mental health in older adults: Extant knowledge for nursing. Journals.lww.com. Retrieved from http://journals.lww.com/familyandcommunityhealth/citation/1991/07000/spirituality_and_mental_health_in_older_adul ts_.4.aspx

Helliwell, J. F., Layard, R., \& Sachs, J. (2012). World happiness report [2012]. Doi.org. https://doi.org/10.14288/1.0053622

Holkup, P. A., Tripp-Reimer, T., Salois, E. M., \& Weinert, C. (2004). Community-based participatory research: an approach to intervention research with a Native American community. ANS. Advances in Nursing Science, 27(3), 16275. https://doi.org/10.1097/00012272-200407000-00002

Hunter-Hernández, M., Costas-Muñíz, R., \& Gany, F. (2015). Missed Opportunity: Spirituality as a Bridge to Resilience in Latinos with Cancer. Journal of Religion and Health, 54(6), 2367-2375. https://doi.org/10.1007/s10943015-0020-y

Johnson, K., ... K. E.-J. of the A., \& 2005, undefined. (n.d.). The influence of spiritual beliefs and practices on the treatment preferences of African Americans: a review of the literature. Wiley Online Library. Retrieved from http://onlinelibrary.wiley.com/doi/10.1111/j.1532-5415.2005.53224.x/full

Kinsella, K., \& Phillips, D. (2005). Global aging: The challenge of success. Retrieved from http://ereserve.library.utah.edu/Annual/SOC/3650/Nathenson/soc3650globalaging.pdf

Learn, C. (1996). Older women's experience of spirituality: Crafting the quilt. Retrieved from https://scholar.google.com/scholar?hl=en\&as_sdt=0\%2C5\&q=Learn+CD.+Older+women's+experience+of + spirituality $\% 3 \mathrm{~A}+$ Crafting+the+quilt.+New+York\%3A+Garland\%3B+1996\&btnG=

Lewis-Williams, D. J., \& Pearce, D. G. (2004). San spirituality: roots, expression, and social consequences. Rowman Altamira.

Lewis, J., \& Tollefsen, I. (2016). The Oxford handbook of new religious movements. Retrieved from https://books.google.com/books?hl=en\&lr=\&id=HZdHDAAAQBAJ\&oi=fnd\&pg=PP1\&dq=The+Oxford+Handbook+ 
of+Sociology+of+Religion.+Oxford:+Oxford++University+Press.+\&ots=TqFMnuvv9o\&sig=dlzm7n_XkQGnkJnMyCYC-_8_kk

Lubben, J., Gironda, M., Berkman, B., \& Harootyan, L. (2003). Social work and health care in an aging society.

M., 1. Johnson. (2009). Spirituality, finitude and theories of the lifespan. In S. M. Bengston V, Gans D, Putney N (Ed.), Handbook of theories of aging (p. 659-674.). Springer.

MacKinlay, E., \& Burns, R. (2017). Spirituality promotes better health outcomes and lowers anxiety about aging: The importance of spiritual dimensions for baby boomers as they enter older adulthood. Journal of Religion, Spirituality \& Aging, 1-18. https://doi.org/10.1080/15528030.2016.1264345

McFadden, S. H. (2005). Points of connection: Gerontology and the psychology of religion. Handbook of the Psychology of Religion and Spirituality, 162-167.

Moberg, D. O. (2005). Research in Spirituality, Religion, and Aging. Journal of Gerontological Social Work, 45(1-2), 11-40. https://doi.org/10.1300/J083v45n01_02

National Population Commission (NPC) [Nigeria] and ICF International. (2013). NIGERIA DEMOGRAPHIC AND HEALTH SURVEY 2013 National Population Commission Federal Republic of Nigeria, 538.

Niederman, R. (1999). The conceptualization of a model of spirituality. Retrieved from https://scholar.google.com/scholar?hl=en\&as_sdt=0\%2C5\&q=niederman+1999+spirituality\&btnG=\&oq=Niederman\% $2 \mathrm{C}+1999+\mathrm{spi}$

of, T. C.-F. in S. T. J., \& 1998, undefined. (n.d.). Incorporating spirituality into social work practice: A review of what to do. Familiesinsocietyjournal.org. Retrieved from http://www.familiesinsocietyjournal.org/doi/abs/10.1606/10443894.719

Omar, R. (1999). Being Old in Malaysia : Issues and Challenges of Older Women, (Ewing).

Peterson, P. G. (2001). A graying world. Harvard International Review, 23(3), 66-75. Retrieved from https://www.lib.uwo.ca/cgi-

bin/ezpauthn.cgi?url=http://search.proquest.com/docview/230969168?accountid=15115\%5Cnhttp://vr2pk9sx9w.search .serialssolutions.com/?ctx_ver=Z39.88-2004\&ctx_enc=info:ofi/enc:UTF-

8\&rfr_id=info:sid/ProQ\%3Aabiglobal\&rft_val_fmt=info

Pickard, J. G., \& Nelson-Becker, H. (2011). Attachment and Spiritual Coping: Theory and Practice With Older Adults. Journal of Spirituality in Mental Health, 13(2), 138-155. https://doi.org/10.1080/19349637.2011.565239

Puchalski, C., Ferrell, B., Virani, R., Otis-Green, S., Baird, P., Bull, J., ... Sulmasy, D. (2009). Improving the Quality of Spiritual Care as a Dimension of Palliative Care: The Report of the Consensus Conference. Journal of Palliative Medicine, 12(10), 885-904. https://doi.org/10.1089/jpm.2009.0142

Seicol, S. R. (2005). A Pastoral Understanding of Positive Aging. Journal of Gerontological Social Work, 45(3), 293 300. https://doi.org/10.1300/J083v45n03_03

Shofoyeke, A., \& Amosun, P. (2014). A Survey of Care And Support for the Elderly People in Nigria. Mediterranean Journal of Social Sciences. Retrieved from http://www.mcser.org/journal/index.php/mjss/article/view/4820

social, R. K.-H. of aging and the, \& 1985, undefined. (n.d.). The social context of death and dying. York: Van Nostrand Reinhold Co, Inc. $\quad$ Retrieved https://scholar.google.com/scholar?hl=en\&as_sdt=0\%2C5\&q=Kalish+R\%3A+\%2C+1985+death\&btnG=

Staude, J.-R. (2005). Autobiography as a Spiritual Practice. Journal of Gerontological Social Work, 45(3), 249-269. https://doi.org/10.1300/J083v45n03_01

Steinhauser, K. E., Alexander, S. C., Byock, I. R., George, L. K., Olsen, M. K., \& Tulsky, J. A. (2008). Do Preparation and Life Completion Discussions Improve Functioning and Quality of Life in Seriously Ill Patients? Pilot Randomized Control Trial. Journal of Palliative Medicine, 11(9), 1234-1240. https://doi.org/10.1089/jpm.2008.0078

Steptoe, A., Deaton, A., \& Stone, A. A. (2015). Subjective wellbeing, health, and ageing. Lancet (London, England), 385(9968), 640-648. https://doi.org/10.1016/S0140-6736(13)61489-0 
Susan H. McFadden. (2005). Points of Connection: Gerontology and the Psychology of Religion. (RAYMOND F. PALOUTZIAN \& CRYSTAL L. PARK, Eds.). NEW YORK LONDON. Retrieved from http://library.aceondo.net/ebooks/Religious_Studies/handbook_of_the_psychology_of_religion.pdf\#page=181

the, W. A.-H. of aging and, \& 1985, undefined. (n.d.). Societal perceptions of aging and the aged. Van Nostrand Reinhold Company.

Thibault, J., Care, R. M.-P., \& 1993, undefined. (n.d.). Recognition and treatment of substance abuse in the elderly. Europepmc.org. Retrieved from http://europepmc.org/abstract/med/8464937

Tornstam, L. (2005). Gerotranscendence: A developmental theory of positive aging. Retrieved from https://books.google.com/books?hl=en\&lr=\&id=J8871LEGDagC\&oi=fnd\&pg=PR5\&dq=Tornstam+Lars.+Gerotransce ndence:+A+developmental+theory+of+positive+aging.+New+York:+Springer\%3B+2005.\&ots=8eV3Mv_vtd\&sig=mS PKOJPKwOQxrY_bsQqx4FAqOQ

United Nations Population Fund (UNFPA), \& and HelpAge Internationa. (2012). Ageing in the Twenty-First Century: A Celebration and A Challenge. United Nations Population Fund (UNFPA), New York, and HelpAge International, London. https://doi.org/978-0-89714-981-5

Vahia, I. V., Depp, C. A., Palmer, B. W., Fellows, I., Golshan, S., Thompson, W., ... Jeste, D. V. (2011). Correlates of spirituality in older women. Aging \& Mental Health, 15(1), 97-102. https://doi.org/10.1080/13607863.2010.501069

Values, W. A.-, ethics, undefined, Lesnoff, and aging/edited by G., \& 1985, undefined. (n.d.). Religion in the lives of the elderly: Contemporary and historical perspectives. Agris.fao.org. Retrieved from http://agris.fao.org/agrissearch/search.do?recordID=US201301396638

Wong, P., Reker, G., handbook, G. G.-D. anxiety, \& 1994, undefined. (n.d.). Death Attitude Profile-Revised: A multidimensional measure of attitudes toward death. Books.google.com. Retrieved from https://books.google.com/books?hl=en\&lr=\&id=CRvGZBrzud0C\&oi=fnd\&pg=PA121\&dq=Wong,+Reker,+\%26+Ges ser,+1994\&ots=x4B2DEjiyh\&sig=-XBVbV_zWD8GgbzIYGMMy7cLjHg

Work, D. M.-J. of G. S., \& 2005, undefined. (n.d.). Research in spirituality, religion, and aging. Taylor \& Francis. Retrieved from http://www.tandfonline.com/doi/abs/10.1300/j083v45n01_02

Work, P. S.-S., \& 1994, undefined. (n.d.). Our clients, ourselves: The spiritual perspective and social work practice. Academic.oup.com. Retrieved from https://academic.oup.com/sw/article-abstract/39/2/178/1908814

Yip, W. W. (2011). Reconstructing John Hick's theory of religious pluralism: a Chinese folk religion's perspective, 1426.

Zimmer, Z., Jagger, C., Chiu, C.-T., Ofstedal, M. B., Rojo, F., \& Saito, Y. (2016). Spirituality, religiosity, aging and health in global perspective: A review. SSM - Population Health, 2, 373-381. https://doi.org/10.1016/j.ssmph.2016.04.009

Zinnbauer, B. J., \& Pargament, K. I. (2005). Religiousness and Spirituality. Handbook of the Psychology of Religion and Spirituality. Retrieved from http://search.ebscohost.com/login.aspx?direct=true \&db=psyh\&AN=2006-00771002\& site $=$ ehost-live 